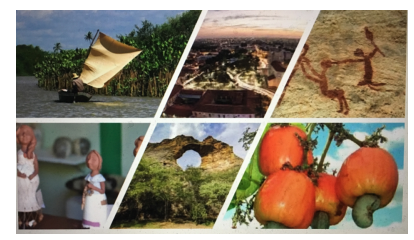

\title{
UM TRAÇO DE GRAÇA SEM GRAÇA NENHUMA: HANS HEILBORN NAS CHARGES DOS JORNAIS CARIOCAS (1914-1915)
}

\author{
Heloisa Helena Meirelles dos Santos \\ Doutora em Educação pela Universidade do Estado do Rio de Janeiro \\ Lattes Id: http://lattes.cnpq.br/0557807770746922
}

Investigar, através das charges publicadas nos jornais cariocas - tomadas na investigação como traços de graça sem graça nenhuma - o alemão naturalizado brasileiro, Hans Heilborn, nomeado diretor da Escola Normal do Distrito Federal pelo Prefeito Rivadávia Corrêa, durante os anos iniciais da $1^{a}$ Guerra Mundial, é o objetivo desta pesquisa. O estudo apresenta a germanofobia existente na cidade do Rio de Janeiro, retratada e estimulada diariamente pelos jornais cariocas e os embates cotidianos do diretor com normalistas e professores francófilos. Recupera fragmentos significativos da memória do educandário formador de professores primários, apresentando a liderança da imprensa para envolver a cidade, e o país, em conflito ideológico a partir de um confronto bélico entre franceses e ingleses contra alemães, em que o Brasil só entrará oficialmente, em 1917. A pesquisa reflete a partir dos conceitos de Ricoeur (2003 e 2007) e Nora $(1979,1993)$, que a História está imersa e diluída na memória coletiva do olhar exterior através da reapropriação do passado histórico, representada no estudo pelas charges dos jornais cariocas. Por fontes privilegiadas a investigação usa os jornais com circulação na cidade do Rio de Janeiro, então Distrito Federal, no acervo da Biblioteca Nacional brasileira.

Palavras-chave: Hans Heilborn. Charges. Escola Normal do Distrito Federal. Cidade do Rio de Janeiro. Conflito ideológico.

\section{A TRACE OF GRACE WITHOUT GRACE NONE: Hans Heilborn in the cartoons of Rio's newspapers (1914-1915)}

\begin{abstract}
Abstrat
To investigate, through the cartoons published in the Rio's newspapers - taken in the investigation as traces of no grace - the Brazilian naturalized German, Hans Heilborn, appointed director of the Escola Normal do Distrito Federal by Mayor Rivadávia Corrêa, during the early years of World War I, is the purpose of this research. The study presents the germanophobia existing in the city of Rio de Janeiro, portrayed and stimulated daily by the Rio's newspapers and the daily clashes of the director with normalists and francophile teachers. Recovers significant fragments of the memory of the primary school teacher educator, presenting the press leadership to engage the city, and the country, in ideological conflict from a war between French and English against Germans, in which
\end{abstract}




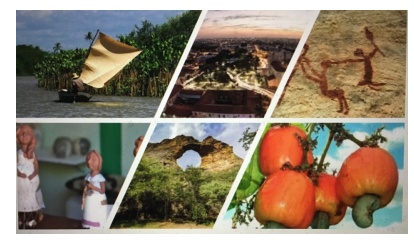

Brazil will only officially enter, in 1917. The research reflects from the concepts of Ricoeur $(2003,2007)$ and Nora $(1979,1993)$, that History is immersed and diluted in the collective memory of the external gaze through the reappropriation of the historical past, represented in the study by the cartoons. from Rio's newspapers. By privileged sources the research uses newspapers circulating in the city of Rio de Janeiro, then Federal District, in the collection of the Brazilian National Library.

Keywords: Hans Heilborn. Rio's Cartoons. Escola Normal do Distrito Federal. City of Rio de Janeiro. Ideological conflict.

\section{UN RASTREO DE GRACIA SIN GRACIA NINGUNO: Hans Heilborn em las caricaturas de los periódicos de Río} (1914-1915)

\section{Resumen}

Para investigar, a través de las caricaturas publicadas en los periódicos de Río, tomadas en la investigación como huellas de no gracia, el alemán naturalizado brasileño, Hans Heilborn, nombrado director de la Escola Normal do Distrito Federal por la alcaldesa Rivadávia Corrêa, durante los primeros años de la Primera Guerra Mundial, es el propósito de esta investigación. El estudio presenta la germanofobia existente en la ciudad de Río de Janeiro, retratada y estimulada diariamente por los periódicos de Río y los enfrentamientos diarios del director con los normalistas y los maestros francófilos. Recupera fragmentos significativos de la memoria institución de formación docente de la escuela primaria, presentando el liderazgo de la prensa para involucrar a la ciudad y al país, en un conflicto ideológico de una guerra entre franceses e ingleses contra alemanes, en la que Brasil ingresará oficialmente. en 1917. La investigación refleja a partir de los conceptos de Ricoeur (2003 y 2007) y Nora $(1979,1993)$, que la Historia está inmersa y diluida en la memoria colectiva de la mirada externa a través de la reapropiación del pasado histórico, representada en el estudio de las caricaturas. de los periódicos de rio. Por fuentes privilegiadas, la investigación utiliza periódicos que circulan en la ciudad de Río de Janeiro, luego Distrito Federal, en la colección de la Biblioteca Nacional de Brasil.

Palabras clave: Hans Heilborn. Caricaturas. Escola Normal do Distrito Federal. Ciudad de Rio de Janeiro. Conflicto ideológico.

UM TRAÇO DE GRAÇA SEM GRAÇA NENHUMA: Hans Heilborn nas charges dos jornais cariocas 


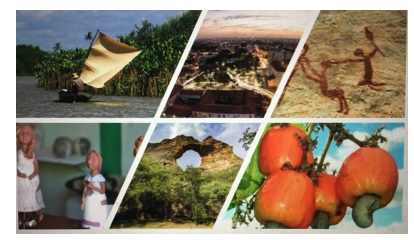

(1914-1915)

\section{Em busca de restos no percurso de historiar}

[...] do jornal local ao diário nacional, do órgão de grande tiragem ao semanário de opinião, somente a imprensa dispõe de uma gama de virtualidades sem rival, um leque excepcionalmente rico de manipulação da realidade (NORA, 1979, p. 182)

Deparei com um período da cidade do Rio de Janeiro e da Escola Normal do Distrito Federal que trata, ideologicamente, de percepções exacerbadas por um conflito externo: a Grande Guerra de 1914. Eu o encontrei incólume nas charges impressas nas páginas dos jornais, por onde perscrutava a História da cidade do Rio de Janeiro. Gosto de pensar que estes restos, de que nos falou Nora $(1979,1993)$, estão dispersos na História da cidade do Rio de Janeiro e da Escola Normal do Distrito Federal e precisam ser analisados juntos. Se assim o fizer eles se tornam ruínas passíveis de serem clarificadas por uma iluminação que enseje, talvez, o que tenham sido no passado a quem, agora, as vê. Resquícios antigos, de um passado onde uma guerra contra a Alemanha era travada pela França e Inglaterra, estavam presentes no discurso dos traços de humor, publicizados pela imprensa carioca, que circularam entre os habitantes de um Rio de Janeiro afrancesado ${ }^{1}$. Estes traços das charges, aparentemente engraçados, mas tratados por seus autores chargistas com muita seriedade, expuseram conflito ideológico entre germanófilos e francófilos, protagonizados pelo diretor alemão ${ }^{2}$ da Escola Normal, Hans Heilborn, que não foi retratado por seus traços físicos nos jornais ${ }^{3}$, e os habitantes da cidade-capital do Brasil. Não sei se cheguei, pela reapropriação, às intenções dos chargistas. Não pude ter a mesma percepção de um personagem do tempo passado, mas

\footnotetext{
${ }^{1}$ A predominância da cultura francesa no Rio de Janeiro tem sido largamente discutida pela historiografia que investiga os primeiros anos do século XX, no Distrito Federal (FARIAS, 2010; ZANON, 2007; SILVA, 2006; CUNHA, 1996; SCHERER, 2010; VELLOSO, 1988; NEVES, 2003; ETC.)

${ }^{2}$ Classifico, de acordo com Gertz (1998), como "alemão" todo aquele que faz uso das especificidades decorrentes do jus sanguinis, independente do País/Estado onde tenha nascido.

${ }^{3}$ Somente as revistas ilustradas (Careta e O Malho) retrataram caricaturalmente Hans Heilborn. Os jornais, talvez pela modernidade que aparentassem ter, somente publicaram fotos dele.
} 


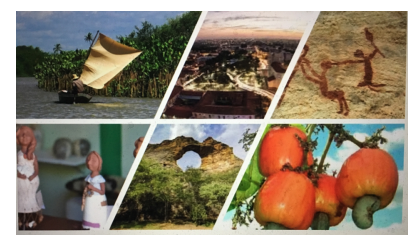

analisei as charges segundo minhas próprias percepções e experiência porque os referentes do texto são constituídos no discurso e posso, como receptora, tê-los reapropiado, ou não, o que não tenho como saber.

Na primeira década do século XX, a cidade do Rio de Janeiro, capital republicana brasileira, efervescia de cultura e ciência. Entre vários eventos importantes, relevantes para sentir a pulsação francófila desse Rio que se foi destaco a direção do Jardim Botânico do Rio de Janeiro (JBRJ) pelo botânico inglês John Christopher Willis. Willis (18681958) administrou o JBRJ no período entre 1912 e 1915, sendo substituído, por Antônio Pacheco Leão ${ }^{4}$, hoje nome de rua do bairro em torno da instituição (CASAZZA, 2012, p. 103). A administração de John Willis, formado em Botânica pela Universidade de Cambridge, imprimiu os primeiros ares científicos à instituição, ainda que pouco se tenha estudado sobre este primeiro movimento científico institucional. A cidade borbulhava em modernidades pontuais que davam ideia de um país novo que se constituía, “civilizadamente” à luz de Paris.

Nesse momento, um conflito na Europa conflagrava diferentes Estados nacionais, alguns fora de suas regiões de origem (HOBSBAWM, 1995). Este conflito, denominado naquele momento Grande Guerra ${ }^{5}$, impactou a capital do país, mas, mesmo assim, foi pouco tratado pela historiografia brasileira em seu desdobramento na cidade do Rio de Janeiro. Esse período permeou, através da imprensa da cidade do Rio de Janeiro, ações, embates e crises que envolveram a Escola Normal do Distrito Federal, associando-a aos medos e reflexos típicos de quem está no front à espera de uma próxima batalha em solo carioca. Foi necessário, portanto, que pudesse interpretar estes traços, aparentemente humorísticos e despretensiosos, publicizados pelos jornais, tomando-os por discursos de

\footnotetext{
${ }^{4}$ Willis edita a primeira revista científica da instituição “Archivos do Jardim Botânico do Rio de Janeiro" (1915).

${ }^{5}$ A designação 1a guerra mundial surge somente em setembro de 1939, por uso na revista Time, para diferenciá-la da segunda. Até então se usava a expressão "Grande Guerra" para designar o conflito bélico de 1914 (SONDHAUS, 2013, p. 15).
} 


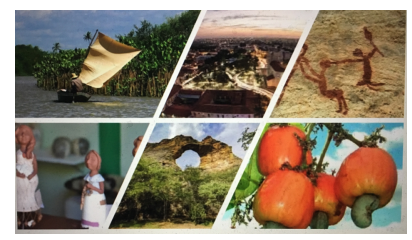

representações (CHARTIER, 1990) ${ }^{6}$ com o conhecimento que hoje tenho desse confronto bélico para o mundo, que não tinha como abstrair. Era aquele o período de gestão do diretor da Escola Normal do Distrito Federal, Hans Heilborn, alemão naturalizado brasileiro, personagem que escolhi como caminho historiográfico desta pesquisa, e que protagonizou para a imprensa carioca o "perigo alemão"7. Quem era esse homem que deu motivo às minhas indagações, próprias de quem historia, e que é o objeto dessa pesquisa? O que foi o "perigo alemão"?

\section{Hans Heilborn: o perigo alemão}

Quando Hans Heilborn nasceu em Berlin, a 15 de junho de 1857, não existia a Alemanha, apenas uma Confederação, de 39 Estados independentes, estabelecidos como União Aduaneira (Deutscher Zollverein). A partir desse ajuntamento comercial de Estados independentes começa a nascer a necessidade de união permanente destes Estados não só naqueles termos, mas configurando uma unificação política. Quando Hans fazia 13 anos, ainda estudante do Colégio Saint Louis, de Heidelberg, Otto Eduard Leopold von Bismarck-Schönhausen, Príncipe de Bismarck, Duque de Lauenburg lançou as bases do $2^{\circ}$ Reich (1871-1918) ${ }^{8}$, constituindo o Estado alemão. Hans formou-se médico na Universidade Heidelberg, a mais antiga da Alemanha ${ }^{9}$. Ao migrar para o Brasil, Hans Heilborn exerce a Medicina na cidade de São João de Montenegro, no Rio Grande do Sul.

\footnotetext{
6 Tomo "representações" no sentido de instrumentos teórico-metodológico de análise da História cultural, isto é, "identificar o modo como em diferentes lugares e momentos uma realidade social é construída, pensada, dada a ler" (CHARTIER, 1990, p. 16)

${ }^{7}$ Ver GERTZ (1998 e 2008).

${ }^{8}$ Existiu desde a Unificação alemã até a derrota do Kaiser Guilherme II na 1á Guerra, com controle da Prússia.

${ }^{9}$ Não consegui saber se Hans, no Brasil, volta a Heidelberg, para a Faculdade, ou se vem, migrando, após a Faculdade. Muito pouco consegui saber dele. Tudo que obtive de conhecimento durante a pesquisa encaminhei ao Instituto Instituto Martius-Staden de Ciências, Letras e Intercâmbio Cultural BrasileiroAlemão, instituição de utilidade pública, sem fins lucrativos, mantida pela Fundação Visconde de Porto Seguro, que visa preservar as relações culturais entre Brasil e Alemanha. O Instituto disponibiliza ao público um dos maiores acervos sobre imigração alemã para o Brasil, através de documentos, jornais, livros, mapas, fotografias e outros materiais e nada sabia sobre Hans Heilborn.
} 


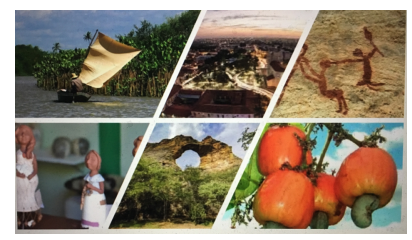

E aqui não posso deixar de destacar que, desde 1850, médicos alemães clinicavam nos núcleos de colonização do sul do país ${ }^{10}$ (BENCHIMOL, 2013). Naquele momento, e até o advento da $1^{\text {a }}$ Guerra, segundo a Memória do Instituto Oswaldo Cruz, até os trabalhos científicos aqui se faziam eram publicados em português e alemão (ibidem). Em 1891, já no Rio de Janeiro, em sociedade com o Dr. Draener, funda o Colégio BrasileiroAlemão ${ }^{11}$, no bairro de Laranjeiras. Mais tarde (1893), radicado em Petrópolis, funda colégio com o mesmo nome, sob sua exclusiva direção, fixando residência em Petrópolis. Ao abrir-se o Ginásio Oficial daquela cidade serrana, em 1899, é nomeado Lente Catedrático da Cadeira de Alemão, e por concurso, em 1901, Catedrático da Cadeira de Grego do Ginásio Nacional ${ }^{12}$, na cidade do Rio de Janeiro. Em 1907, Hans Heilborn é convidado pelo presidente da república, Affonso Penna ${ }^{13}$, para representar o Brasil na Comissão de Propaganda e Expansão do Brasil na Europa , p.3 $)^{14}$, em missão oficial do governo, para vender o café brasileiro ${ }^{15}$ (O Século, 19 de outubro de 1909 e A Rua, 6 de dezembro de 1914, p.1).

Ao final de 1914, Hans Heilborn é nomeado, pelo Prefeito do Distrito Federal, Rivadávia Corrêa, como diretor da Escola Normal (A Notícia, 12-13 de dezembro de 1914, p. 1), cargo que ocupa até julho de 1915. Ao assumir o cargo de diretor, Hans Heilborn passa a ser acusado pela imprensa carioca que a ele atribui o protagonismo de

\footnotetext{
10 “As colônias agrícolas no interior do Brasil e as comunidades estrangeiras de suas cidades litorâneas atraíram médicos, boticários e cirurgiões para lidar com os problemas de saúde enfrentados por aqueles europeus em seu processo de 'aclimatação' a uma zona do planeta considerada, então, hostil a sua sobrevivência" (BENCHIMOL, 2013, p.108)

${ }^{11}$ Segundo Seyferth (2011), na ausência de escolas públicas, os alemães organizaram um sistema de escolas comunitárias, sem fins lucrativos, que, juntamente com as escolas particulares ensinavam em alemão. Seus currículos enfatizavam a cultura e a história alemã.

${ }^{12}$ Antes da república designado Colégio de Pedro II.

${ }^{13}$ Affonso Augusto Moreira Penna (30 de novembro de1847- 14 de junho de 1909) foi o 6o presidente da república brasileira não tendo concluído, por morte, seu mandato. Pertencia ao Partido Republicano Mineiro. Foi substituído por Nilo Peçanha. (LACOMBE, 1986)

14 "Proclamada a República, e eliminados os chamados obstáculos internos à consolidação do novo regime [...], as elites republicanas empenharam-se de forma sistemática na substituição da imagem do Brasil pitoresco por outra capaz de inserir o país no circuito das nações industrializadas e civilizadas" (BORGES, 2007, p.93).

${ }^{15}$ Affonso Penna desenvolvia política de valorização do café brasileiro. Ver LACOMBE, 1986.
} 


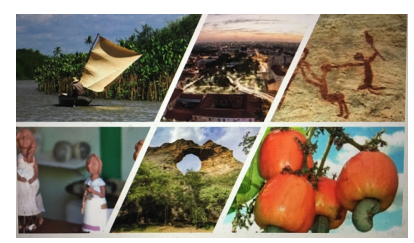

ser alemão em uma cidade francófila. A princípio a imprensa alega que a Escola Normal já possuía um diretor adido e que ele, um alemão, tomara seu lugar com maior vencimento (A Noite, 4 de dezembro de 1914, p.2); depois, pela manifestação de alunos, pais e professores, em artigos e cartas aos jornais (A Época, 23 de junho de 1915, p.2) ${ }^{16}$, contrapondo sua nacionalidade germânica em momento de uma guerra contra a Alemanha. A seguir, por Brício Filho, professor da Escola Normal, dono e redator de "O Século", por não the ter concedido uma gratificação de docência que solicitara em processo formal ${ }^{17}$.

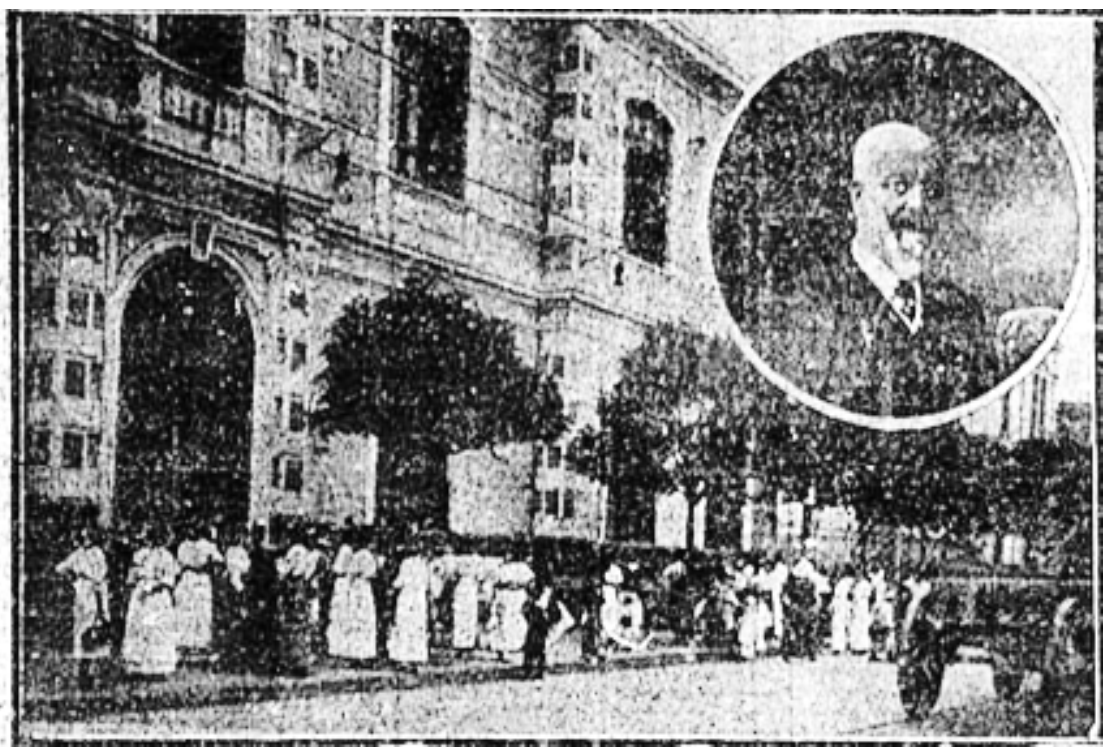

Figura 1. O caso das Normalistas. Uma conflagração na Escola Normal.

Fonte: BN, Hemeroteca. Gazeta de Notícias, 15 de junho de 1915, p. 1.

\footnotetext{
${ }^{16}$ Ver AUTOR, 2018.

17 "Em diversas notas temos trazido a público os escândalos praticados pelo diretor da Escola Normal, quer matriculando naquele estabelecimento alunas contra a lei, algumas até reprovadas em concurso, quer mandando corrigir o resultado de exames, para serem consideradas aprovadas simplesmente, normalistas que tinham sofrido reprovação[....] 0 alemão, por proteção aos que houvessem sido auxiliares de ensino[...] Eis ai mais uma do estrangeiro que veio moralizar a Escola Normal[...]". (O Século, 24 de junho de 1915, p. 1)
}

Revista Caminhos da Educação: diálogos, culturas e diversidades. CAEDU/UFPI 


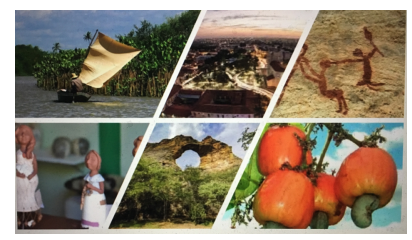

Segundo os jornais opositores de Hans Heilborn, ele não permitira que as alunas fossem, durante o período das aulas, às comemorações do Cinquentenário da Batalha do Riachuelo $^{18}$ (O Imparcial, 12 de junho de 1915, p.2, A Época, 12 de junho de 1915, p.1, O Século, 14 de junho de 1915, p.1-2, A Rua, 19 de junho de 1915, p.2) $)^{19}$; mandara "macular a honra de uma donzela", ao designar que um homem que não era médico (um funcionário da Escola Normal) atendesse a normalista após ela ter desmaiado, ainda que o dr. Brício Filho as tivesse, também, atendido ( $A$ Rua, 15 de junho de 1915, p.2 e $O$ Século, 17 de junho de 1915, p.1 e 18 de junho de 1915, p.3); de ser "bruto", ríspido" e “bárbaro"(Correio da Manhã, 12 de junho de 1915, p. 2 e O Século, 14 de junho de 1915, p.1 e 19 de junho de 1915, p.1), características próprias da representação que se fazia do povo germânico. Mas não era só isso!

[..] ninguém aqui se tem voltado contra os numerosos estrangeiros que ensinam em nossos estabelecimentos. O próprio Hans Heilborn tem sido professor do Colégio Pedro II e nunca este fato levantou protesto. O que não se pode admitir é que, dirigindo um instituto de ensino, para moças, insulte os brasileiros, proclame a imoralidade reinante em nosso país, trate as meninas com brutalidade, desconsidere um grupo inteiro de funcionários pedindo, por imoral, a sua remoção da secretaria da Escola, praticando outras insolências [...] (O Século, 18 de junho de 1915, p.1)

Hans Heilborn era acusado, também, de insultar o professor Francisco Cabritta (A Noite, 12 de junho de 1915, p.2 e 16 de junho de 1915, p.3), um ex-diretor da Escola Normal; de suprimir o lugar de eletricista da Escola Normal para poupar despesas (O Século, 25 de junho de 1915, p.1); de mudar o endereço da Escola Normal da Praça da Aclamação para o Estácio à Rua São Cristóvão ${ }^{20}$; de mandar fechar a Escola Normal por desordem das normalistas (A Noite, 27 de junho, p.3 e $O$ Século, 16 de junho de 1915,

\footnotetext{
${ }^{18}$ Considerada uma das batalhas decisivas na guerra brasileira contra o Paraguai (Guerra da Tríplice Aliança), foi travada no dia 11 de julho de 1865 às margens do rio Riachuelo, na Argentina(NUNEZ, 2011)

${ }^{19}$ A Rua, 23 de junho de 1915, p.3.

${ }^{20}$ Ver AUTOR, 2013.
}

Revista Caminhos da Educação: diálogos, culturas e diversidades. CAEDU/UFPI 


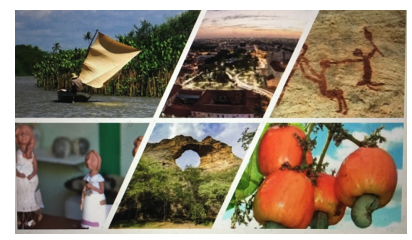

p.1) de ter pedido exoneração do cargo de diretor ao diretor da Instrução Pública e ao Prefeito (A Noite, 25 de junho de 1915, p.3) sem sucesso ${ }^{21}$, mas, tendo a crise chegado ao presidente da república, Wenceslau Brás, foi aceita a solicitação ( $O$ Século, 28 de junho de 1915, p.1, A Rua, 16 de junho de 1915, p.2 e $A$ Época, 9 de julho de 1915, p.3222. Hans Heilborn retorna à Petrópolis onde morre, em 20 de dezembro de 1916 (A Noite, 21 de dezembro de 1916, p.3), ainda durante a guerra europeia, provavelmente desgostoso das críticas e apupos dos habitantes da cidade do Rio de Janeiro contra ele.

\section{No traço das charges o "perigo alemão"23}

Este momento, da primeira década do século XX, apresenta a imprensa carioca com um novo discurso paradigmático. É a imprensa dos fatos e do repórtercronista, da notícia do fato visto pelo repórter e não relatado por boatos; das opiniões dos diversos articulistas dos impressos; do tempo de ganhar leitores, além dos assinantes do jornal, e fazer dinheiro... Foram representantes destes repórteres-cronistas ${ }^{24}$, João do Rio, da Gazeta de Notícias ${ }^{25}$; Orestes Barbosa, de $A E^{2} p o c a^{26}$ e depois O Século; Edmundo Bittencourt, do Correio da Manha ${ }^{27}$; Antônio Azeredo, d'A Tribuna ${ }^{28}$; José do Patrocínio,

\footnotetext{
21 "A Escola Normal - O sr. Hans Heilborn pede novamente demissão. O prof. Hans Heilborn volta a pedir demissão desse cargo, tendo hontem dirigido ao prefeito a carta que abaixo publicamos. Dada a insistência com que o sr. Heilborn tem reiterado esse pedido, o dr. Rivadávia Corrêa está resolvido a atendel-o [...]" (Correio da Manhã, 27 de junho de 1915, p. 2. Obedecida a grafia da fonte.)

22 "O presidente da república, sr. Wenceslau Braz, recebeu hontem, às 5 horas da tarde, no Palácio Guanabara, uma commissão de alunos da Escola Normal que lhe foi fazer uma exposição minuciosa dos factos ultimamente ali ocorridos. Nesta exposição foram formuladas as mais positivas acusações ao director daquele estabelecimento de ensino, sr. Hans Heilborn." (Correio da Manhã, 16 de junho de 1915, p.3. Obedecida a grafia da fonte)

${ }^{23}$ Ver GERTZ, 1998, p. 17- 44

${ }^{24}$ Ver BULHÕES, 2007.

${ }^{25}$ Ver VERRUMO, 2014.

${ }^{26}$ Ver DIDIER, 2005.

${ }^{27}$ Ver BRANDÃO e LEITÃO, 1944.

${ }^{28}$ Ver FANAIA, 2015.
}

Revista Caminhos da Educação: diálogos, culturas e diversidades. CAEDU/UFPI

Teresina, Brasil, v. 1, n. 1, p. 80- 112, janeiro/abril de 2019

DOI: 


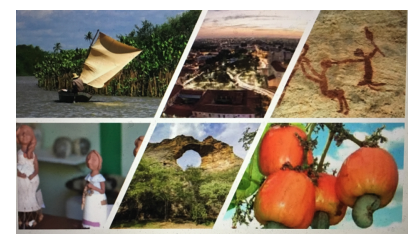

da Cidade do Rio ${ }^{29}$; Alcindo Guanabara, d'A Tribuna ${ }^{30}$ e Arthur Azevedo ${ }^{31}$, d'O Paiz e tantos outros, que diziam trazer a modernidade a confrontar-se cotidianamente a artículos de opinião, as suas, apenas. Costa (2010) afirma que "a expressão opinativa [no jornalismo] é uma expressão ideológica" (p.57) porque reproduz as tensões sociais, e uma das tensões naquele momento era o "perigo alemão". A esse novo discurso da imprensa, inserem-se as fotos, que substituem os desenhos (que ainda aparecem esporadicamente) nos impressos jornalísticos para demonstrar a civilidade e progresso europeu que o Rio de Janeiro desejava ostentar.

Eles eram diferentes! Falavam uma língua incompreensível que ensinavam em suas escolas, uniam-se aos seus próprios compatriotas, sua religião não era a católica, seus hábitos culturais eram diferentes... Gertz (2008, p.122) afirma que o medo do alemão já criara raízes no Brasil muito antes da guerra. Isso ocorre, supõe-se, graças a um memorando, datado de 1826, que orientava a imigração para o Brasil, sugerindo transformar-se o sul do país em um "território alemão". O certo é que no Brasil havia receio de que a Alemanha realmente anexasse o sul o do país e todos os esforços foram feitos, ideologicamente, principalmente na capital da república, para disseminar o que se designou por "perigo alemão". Aos alemães, postulantes da doutrina pangermanista oriunda do século anterior quando este Estado ainda não existia como tal, surgia a possibilidade de anexar territórios em uma nova nação, com quem comerciava em bons termos desde 1808. O "perigo alemão" é bom que se saiba, não nasce na imprensa que dele apenas se apropria, explicitando-o nas charges dos jornais cariocas e compartilhando a todos que temiam o pangermanismo (Alldeutsche Bewegung) ${ }^{32}$.

A hipótese, tida por fato, fora exposta no livro de André Chéradame (editado pela primeira vez em 1916), "Le plan pangermaniste démasqué: le redoutable piège

\footnotetext{
${ }^{29}$ Ver EDMUNDO, 2003.

30 Ver ERTZOGUE, 2010.

${ }^{31}$ (1855-1908) Foi professor do Colégio Pinheiro, na cidade do Rio de Janeiro. Colaborou, também, como articulista, nos jornais A Estação e Novidades e A Notícia (MORASCO, 2008)

32 Ideologia do século XIX, antes da criação da Alemanha, que defendia a união de todos os povos germânicos em um só Estado nacional.
} 


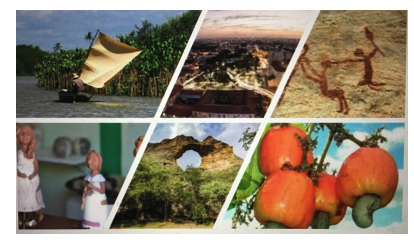

berlinois de "la partie nulle", onde Chérame (2013) afirmava haver um plano germânico para dominar o mundo. A obra agregou um grande número de intelectuais no Brasil, muitos deles professores da Escola Normal. Dentre esses, destaco Manuel Bonfim, Hemetério José dos Santos, Afrânio Peixoto, José Veríssimo, e Francisco Cabritta, todos contra a Alemanha, e contra um alemão, Hans Heilborn, nomeado diretor da escola onde todos eles trabalhavam.

A imprensa carioca, e os professores-jornalistas que ali atuavam como articulistas, não se furtavam de espalhar nas charges o "perigo"! E os professores da Escola Normal enfatizavam todas as atitudes cotidianas de Hans Heilborn como de um inimigo a ser combatido! E ainda que nas charges dos jornais Hans Heilborn não estivesse retratado, o leitor sabia de quem se falava!

Na charge abaixo, na primeira página de um dos maiores jornais do país à época, $O$ Paiz $^{33}$, o chargista faz referência aos submarinos alemães ${ }^{34}$ que eram silenciosos e destruidores e assustavam os aliados durante a $1^{\text {a }}$ guerra. Assim, o traço da charge pode ser visto aqui como sátira, ou metáfora ${ }^{35}$ a um acontecimento político-social-cultural de um dado momento histórico a que se pretendeu dar repercussão e visibilidade, como mensagem subliminar, através deste discurso gráfico que apresenta os alemães como perigosos e traiçoeiros.

\footnotetext{
${ }^{33}$ Fundado em 10 de outubro de 1884 . Seu primeiro proprietário foi o comerciante português João José dos Reis Júnior, Conde de São Salvador de Matozinhos. Deixa de circular em 1934. (LEAL, 2015)

${ }^{34} \mathrm{O}$ primeiro submarino da Marinha Alemã entrou em serviço em 14 de dezembro de 1906, era o U1. Ele tinha 42,2m de comprimento, 283 toneladas de deslocamento, 2 motores de $200 \mathrm{hp}$, fazia 10,8 nós na superfície e 8,7 nós submerso. Tinha tripulação de 12 homens e era armado com um tubo de torpedo, com 3 torpedos a bordo. No total, submarinos alemães causaram a perda de cerca de 6 mil navios dos Aliados. Só o Reino Unido perdeu 13 mil vidas nesses ataques navais. (SORIANO NETO, 2014, p.27)

35 Aqui entendido no sentido de Lacan (1998) como sustentação do inconsciente estruturado como linguagem: "Há dois públicos, aquele que está aqui, e que tem ao menos uma chance de nortear-se, e o outro, que vem de horizontes bem diferentes, dar uma cheirada no que se passa [...]"(p.31).
} 

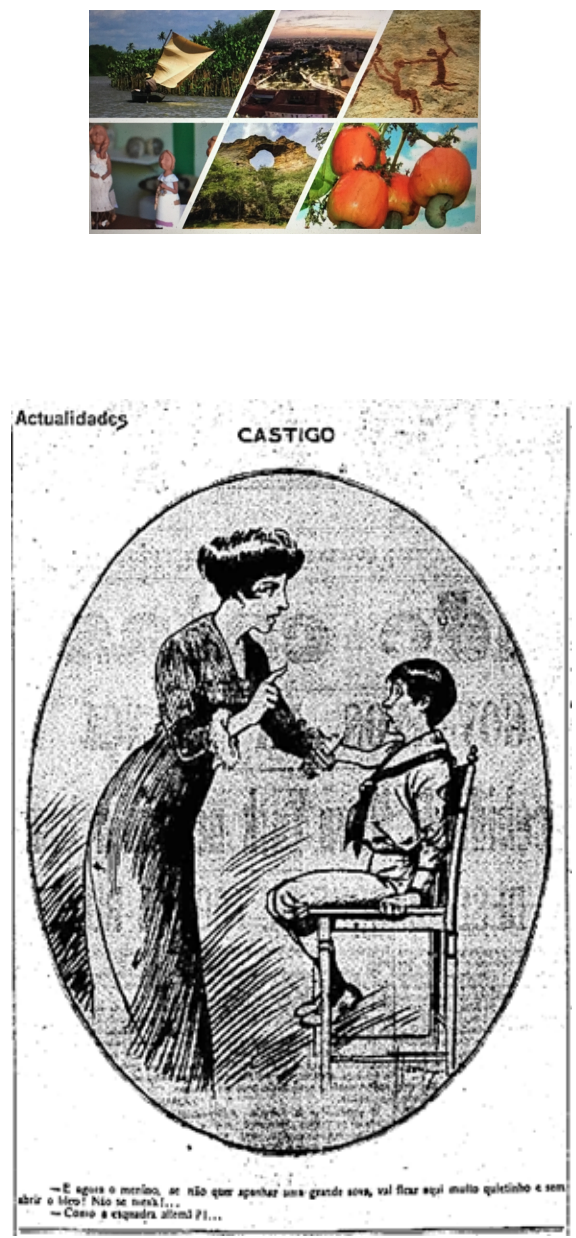

- E agora menino, se não quer apanhar uma grande sova, vai ficar muito quietinho e sem abrir o bico! Não se mexa!...

- Como a esquadra allemã?!...

Figura 2 O Castigo Fonte: BN, O Paiz, 10 de setembro de 1914, p.1

Esta charge não usa o traço estilizado para visualizar o personagem, ou caricaturá-lo. Não há uma figura reconhecível pelo leitor na imagem. Mas o leitor sabe do que e de quem trata o desenho! O chargista inominado ${ }^{36}$ usa o texto e o traço para comunicar-se através da imagem e escritura, com um discurso referencial a reforçar o outro, dando mais peso ao que mostra e escreve. Não tive a pretensão de conhecer a autoria de todas as charges que pesquisei, mas a investigação permitiu-me achar alguns indícios plausíveis de autoria.

\footnotetext{
${ }^{36}$ Poucos artistas assinavam sua obra que era reconhecida pelo talhe do desenho do autor, ou uso de um dado personagem como Zé Povo, por exemplo. (RIBEIRO, 2009)

Revista Caminhos da Educação: diálogos, culturas e diversidades. CAEDU/UFPI 


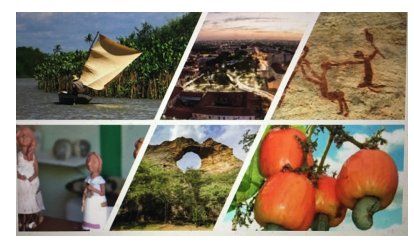

Naquele momento o Brasil, que recentemente abolira a escravidão, instaurara a república por regime e pretendia ser uma Paris dos trópicos, estava recebendo um grande contingente de migrantes que não conheciam a língua pátria e poucos eram os alfabetizados em português. Todos esses migrantes vinham em busca de um paraíso, que não encontraram, ou para ver o exótico, com que nos propagandeavam. Por conta da pouca alfabetização dos habitantes do Rio de Janeiro, um mesmo jornal era normalmente "lido" por muitos, brasileiros e estrangeiros pouco fluentes na língua nativa, porque a leitura de um sujeito era partilhada oralmente por outros, mas as imagens não. Qualquer um podia "ler" as imagens, ainda que a integralidade do pensamento do autor ao desenhar o evento e os personagens não fosse a todos perceptível! E por que essa apropriação?

A elite da população no Rio de Janeiro sonhava ser parisiense. A França, tida por berço da civilização ocidental, encantava os eruditos e os não eruditos. Falava-se francês nas ruas do Rio. Os cardápios dos restaurantes eram em francês. Alguns objetos eram designados em francês: o soumier, le manteau, le chauffeur... A Escola Normal oferecia livros em francês e esta era uma das Cadeiras de seu currículo. Os filhos homens das elites iam estudar em Paris e voltavam arrastando um francês que consideravam impecável. Era chic! E essa disposição de tornar o habitante da cidade um francês, transmutava a Rua da Ouvidor em Rue Vivienne! 

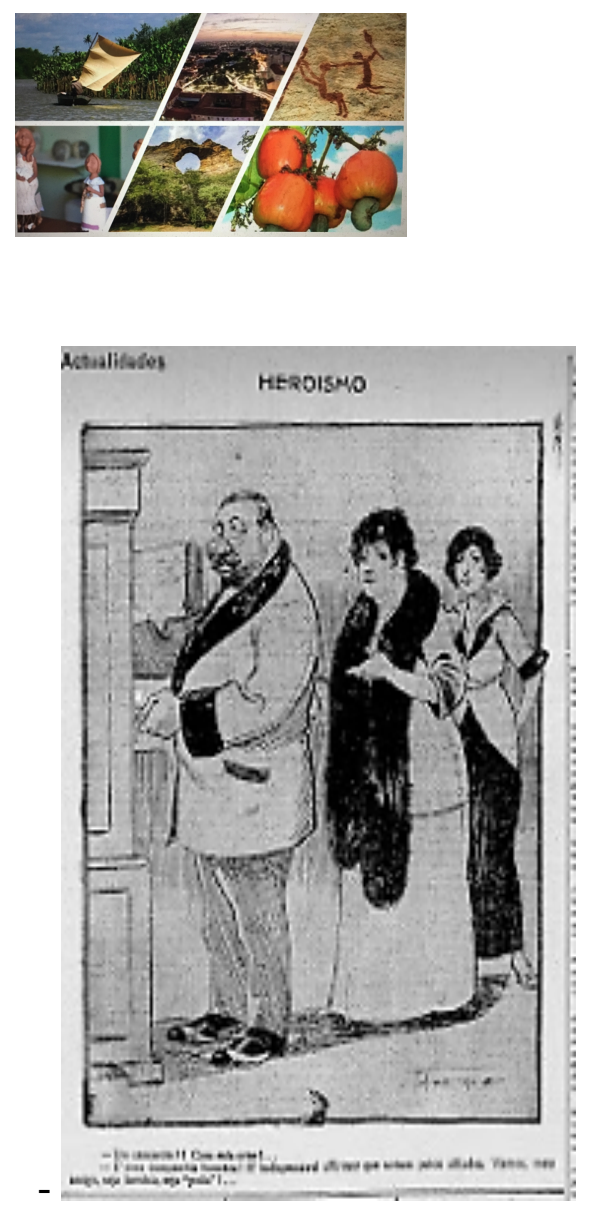

- Um camarote? Com essa crise?...

- É uma companhia franceza! É indispensável affirmar que somos pelos aliados!

Vamos, meu amigo, seja heroico, seja "poliu"!... 37

Figura 3 Heroismo Fonte: BN, Hemeroteca, O Paiz, 29 de junho de 1915, p.2

Como uma cidade-sede da capital do país, no comando das decisões políticas e econômicas, o Rio de Janeiro, em fase cosmopolita, buscava acompanhar o progresso europeu, especialmente o francês. As propagandas ostentavam, como novidade, o trompe-l'oeil ${ }^{38}$; o texto dos jornais diários enchiam de galicismos seus artigos, como se estivéssemos, em pleno Rio de Janeiro, no front francês! A cidade, assim como seus

\footnotetext{
${ }^{37}$ Obedecida a grafia da fonte.

${ }^{38}$ Truque de perspectiva ótica.
}

Revista Caminhos da Educação: diálogos, culturas e diversidades. CAEDU/UFPI

Teresina, Brasil, v. 1, n. 1, p. 80-112, janeiro/abril de 2019

DOI: 


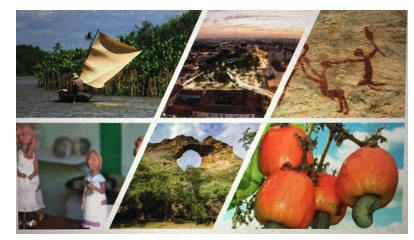

habitantes, alinhava-se aos padrões culturais parisienses, na tentativa de sair do provincianismo, perseguindo o modelo que a imprensa acompanhava, e incentiva subliminarmente, através das charges. Tal alinhamento ideológico incluiu, na época do conflito bélico de 1914, estar do lado francês, falar francês e vestir-se como francês. Observe, leitor, o robe de chambre e a gola de pele, no vestuário usado pelos personagens do chargista, no tórrido calor carioca!

As charges dos jornais diferiam das charges das revistas ilustradas. Nos jornais elas tinham poucos traços, e pouco espaço no corpo físico do periódico, nenhuma cor e, nem sempre, a mesma liberalidade criativa das revistas para o chargista-ilustrador projetar na cena, e no texto, a ideologia que lhe conviesse. Nos jornais predominavam humor e sátira através das imagens caricaturais, de modo geral de políticos, e que sempre atingiam a totalidade dos "leitores" que não liam. A estes se possibilitava a reconstrução da representação (RICOEUR, 2000), sem terem que contar com a intervenção de um leitor para outro, intrometendo-se na representação pretendida pelo autor do traço.

Desde o início da guerra na Europa já se viam nos jornais com circulação no Rio de Janeiro, pequenas caricaturas ${ }^{39}$ que retratavam a guerra, associando-a a fatos regionais. Encontrei, em $A$ Noite ${ }^{40}$ de 28 de junho de 1915, auge da crise na Escola Normal, essa pequena charge que ilustra aquele momento e lembra a perda, pela França, durante a guerra franco-prussiana (1870-1871) da região da Alsácia ${ }^{41}$. Importante

\footnotetext{
39 "A rigor, os desenhos de humor desses pioneiros não se parecem com as charges tal como as conhecemos. Hoje[o] traço está ligado criticamente aos problemas da sociedade [Naquele momento] as charges se caracterizavam pela reprodução fidedigna de personagens - a caricatura não havia sido, ainda, incorporada ao grafismo de sua linguagem -, pelo realismo das situações que abordava, fruto de uma sociedade condicionada por uma visão excessivamente cartesiana da realidade, e pela prolixidade de textos que menosprezavam a imagem como portadora de estrutura narrativa própria. (TEIXEIRA, 2001, p. 1)

40 Segundo Ferreira (2015) em artigo do Dicionário Histórico-Biográfico da 1a República, do CPDOC/FGV, o jornal A Noite foi criado em 1911 e extinto em 1957, no Rio Janeiro, por Irineu Marinho e treze outros jornalistas que trabalhavam com ele no jornal Gazeta de Notícias, após desentendimentos com a direção daquele periódico. Foi, como se autodeclarava nos editoriais, um jornal de oposição. No governo Hermes da Fonseca, teve sua circulação suspensa por um período e seus diretores presos.

${ }^{41} \mathrm{~A}$ região foi alvo de disputas entre França e Alemanha desde o século $V$ quando os francos expulsaram os alamanos.
} 


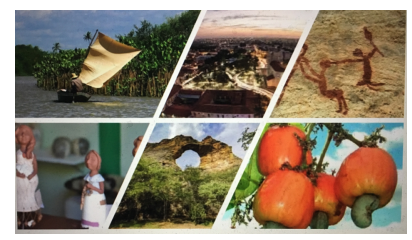

esclarecer que a charge aparece sozinha, mas próxima de textos escritos que relatavam feitos anteriores à guerra europeia, expressando na escritura, que a complementa e refere, fato sabido: de que um alemão dirigia a Escola Normal. Apresenta as normalistas ao deixar a Escola Normal, por "culpa" de Hans Heilborn"2 , tal qual fez a França na região germânica, expulsa pelos alemães no século anterior.

Do "quartel general" (termo típico naquele período belicoso), o diretor da Escola Normal do Distrito Federal, Hans Heilborn, tratado por "general”, que não aparece retratado na caricatura, expulsa "as francesas", normalistas, segundo a propaganda aliada da época ${ }^{43}$. As francesas, "donas do espaço" geograficamente importante, são expulsas porque não podem entrar na escola em que estudavam no Estácio ${ }^{44}$, fechada às estudantes pelos interesses alemães (de Hans Heilborn), como a Alsácia, que fora tomada dos franceses, pelos alemães, em batalha.

\footnotetext{
${ }^{4242}$ As normalistas do curso diurno, em 11 de julho, desejavam assistir comemorações do 50 o aniversário da Batalha do Riachuelo e foram impedidas pelo Diretor que não autorizou a saída. As normalistas do noturno, sabedoras do ocorrido, leram em voz alta trechos de diversos poemas sendo advertidas pela inspetora Maria Luiza por estarem, em horário de aula, ainda no pátio. Depois de discussão entre alunas e a funcionária, o diretor foi chamado e suspendeu a aluna Déa que começara a discussão. A aluna desmaiou, o tumulto foi formado com várias alunas desmaiando. Familiares e os namorados que esperavam na rua a saída das normalistas chamaram a polícia porque os portões da Escola Normal foram trancados impedindo a saída das alunas do curso noturno. O Diretor chamou o Prefeito que fechou a Escola Normal por alguns dias (O Paiz de 15 de julho de 1915, p.1 e $A$ Notícia de 14 de julho de 1915, p.1). ${ }^{43} \mathrm{~A}$ região sempre foi germânica (pertencia ao Sacro Império Romano-Germânico e foi tomada por Luis XIV, em 1648). A França não se conformou em ter de devolver o território após a guerra franco-prussiana (1871), sendo este um dos motivos da guerra de 1914. A região retorna à França pelo Tratado de Versalhes (1919).

${ }^{44}$ Ver AUTOR, 2013.
} 

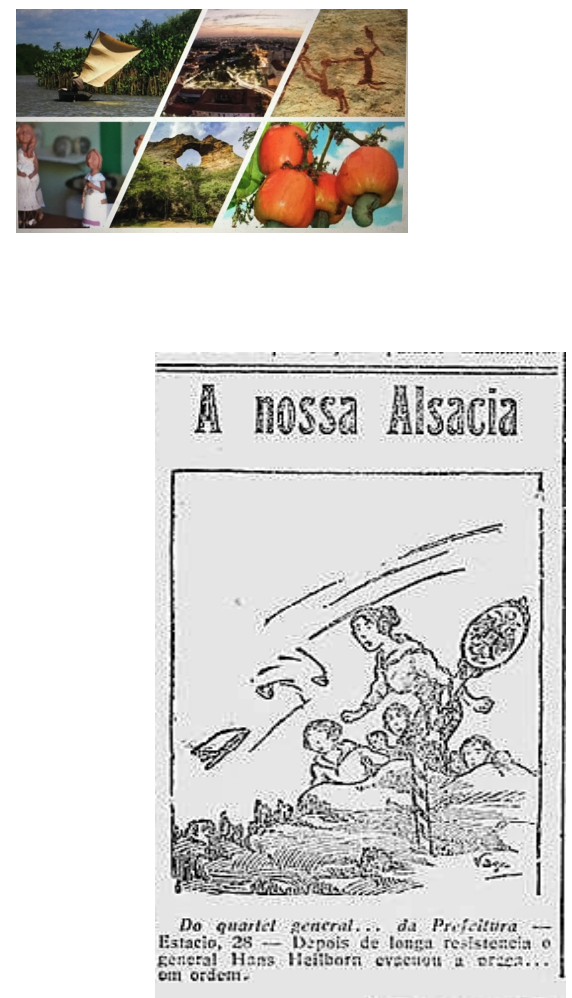

Do quartel general... da Prefeitura - Estácio, 28

- Depois de longa resistência o general Hans Heilborn evacuou a várzea...

em ordem.

Figura 4 A Nossa Alsacia Fonte: BN, Hemeroteca, $A$ Noite, 28 de junho de 1915, p.5

As insinuações da imprensa sobre Hans Heilborn, verdadeiras ou não, a todos lembravam, em período bélico, a nacionalidade do seu contendor e as representações que se faziam dos alemães ${ }^{45}$. O Século, em edição de 12 de janeiro de 1916, quando ainda

45 Em edição de 19 de junho de 1915, p.1, o jornal O Século tem os seguintes leads: "Na Escola Normal. O Dr. Azevedo Sodré. O Inquérito Administrativo. A normalista Cecília Meireles. Os cartões do alemão. Adesões de protesto. O contínuo Abílio. O guarda-civil Nazareth". 


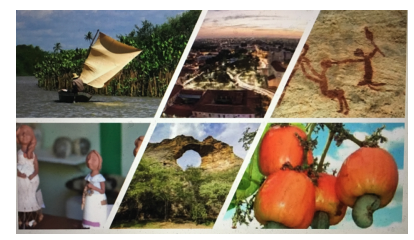

Brício Filho brigava com Rivadávia Corrêa e Azevedo Sodré ${ }^{46}$ sobre o Decreto $\mathrm{n}^{\circ} 981$ de 2 de setembro de $1914^{47}$, sintetiza a opinião de Brício sobre Hans Heilborn, ainda que o ex-diretor da Escola Normal já estivesse morto. Em um trecho daquela publicação desabonadora, Brício refere-se memorialisticamente à mudança de endereço da Escola Normal da seguinte forma:

[...] Nomeado em fins de 1914 Diretor da Escola Normal o Sr. Hans Heilborn começou para aquelle estabelecimento o período da agitação e do sobressalto. O recém-nomeado começou a praticar o processo alemão, para ficar mais perto da estação de Praia Formosa ${ }^{48}$, como morador de Petrópolis, mudou o edifício para a rua de São Christovam ${ }^{49}$ [...] Não esteve disposto a representar o papel de fantoche do diretor prussiano o Dr. Ramiz Galvão e solicitou sua exoneração do cargo ${ }^{50}[\ldots](\mathrm{p} .2)$

Importante esclarecer que “O caso da Escola Normal” nunca foi um só. São vários casos sem importância que ganharam relevância e visibilidade, a denunciar a germanofobia do período que mantinha, durante a Grande Guerra, um alemão à frente da Escola Normal do Distrito Federal:

Foi mal recebida pela opinião pública a nomeação do Sr. Dr. Hans Heilbornn para Diretor da Escola Normal. Todos viram neste acto do Dr. Rivadávia Corrêa a intenção de contrariar deliberação tomada [...] pelo Sr. Presidente da República, de se aproveitar nos cargos que vagarem, os funcionários adidos. O sr. Rivadávia é que não esteve pelos autos. Sobre a nomeação fala-nos nosso collega de imprensa, o Dr.Brício Filho, diretor de 'O Século' [...]

\footnotetext{
${ }^{46}$ Brício Filho foi processado por Azevedo Sodré pelas calúnias que publicou em O Século sobre o Diretor de Instrução, na gestão de Hans Heilborn, conforme charge publicada no O Malho(ed.732, 1916, p.17) ${ }^{47}$ O Decreto reformulava o ensino primário, normal e profissional.

${ }^{48}$ A estação da Praia Formosa foi aberta em 1909, pela Leopoldina Railway e era uma estação provisória para as suas linhas ferroviárias que seguiam para Petrópolis.

${ }^{49}$ Ver AUTOR, 2011

50 Ramiz Galvão já estava desgostoso em 1912, quando perdeu na ABL, para Lauro Müller, a vaga da cadeira antes ocupada pelo Barão do Rio Branco. Em 1914, organizou o I Congresso de História Nacional, do IHGB, adotando, a partir do evento, o patriotismo na sua visão histórica face à deflagração da Primeira Guerra Mundial (GUIMARÃES 2006)
}

Revista Caminhos da Educação: diálogos, culturas e diversidades. CAEDU/UFPI 


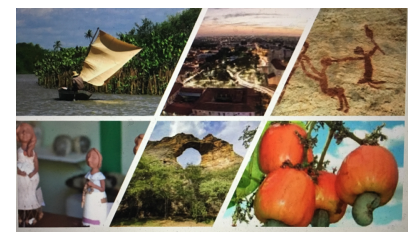

Não entro na apreciação do merecimento da nomeação. Apenas da deliberação do Dr. Wenceslau Brás que não fizessem novas nomeações se existissem funcionários adidos [...] nessas condições a nomeação do Dr. Hans Heilborn não pode ser mantida [...] À hora que o procurávamos o Dr. Abílio Borges, este saia do estabelecimento que dirige à Praia de Botafogo, em direção à cidade [...] -Infelizmente meu amigo [respondendo à pergunta do jornal sobre a nomeação] não os posso atender. Sou suspeito nessa questão, sendo eu o adido que teria de ser chamado. [...] fui colocado em disponibilidade desde o tempo em que o cargo de Diretor da Escola Normal equivalia a Diretor da Instrução Municipal; no tempo em que a Escola Normal tinha autonomia [...] E o Dr. Ab́lio estendeu-nos a mão pedindo que não mais se tocasse no assumpto $[. ..](A \text { Rua, 5/2/1914, p.1 })^{51}$

Ainda que o Rio de Janeiro fosse uma cidade francófila, por que a imprensa voltou-se contra Hans Heilborn? Não existiam outros alemães (naturalizados ou descendentes) ocupando cargos relevantes na cidade? Qual o papel da imprensa na difusão da germanofobia? Quem eram os leitores que se pretendia influenciar?

\section{A imprensa}

Não que não haja diferença entre o fato cotidiano e o acontecimento; mas sobre qualquer acontecimento, no sentido moderno do termo, o imaginário de massa quer poder enxertar qualquer coisa do fato cotidiano: seu drama, sua magia, seu mistério, sua estranheza [...] O imaginário pode, desta forma, apropriar-se de qualquer fato cotidiano [...] (NORA, 1979, p. 186)

A imprensa não parou um dia sequer! Era importante que o sensacionalismo dos fatos cotidianos ocorridos na Escola Normal, e encarados como de autoria de Hans Heilborn (mudança da sede da escola; fechamento dos portões do educandário; desmaios e balbúrdias das alunas; etc.) chegassem a todos! E as notícias destes "acontecimentos" chegavam a muitos jornais, que as repercutiam, porque cada jornal queria tirar proveito de uma fatia de leitores.

\footnotetext{
${ }^{51}$ Obedecida a grafia da fonte.
} 


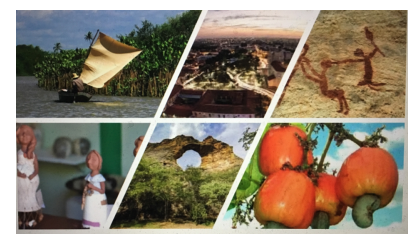

Para materializar o discurso germanofóbico unificado dos jornais contra Hans Heilborn, o quadro abaixo mostra a repercussão do "caso da Escola Normal" ou "caso Hans Heilborn" como era descrito na imprensa do Rio de Janeiro.

Quadro 1

Repercussão do “caso Hans Heilborn”, ou "caso da Escola Normal”, na imprensa cotidiana do Rio de Janeiro

\begin{tabular}{|c|c|c|}
\hline JORNAL & DATAS & ANO \\
\hline \multirow[t]{3}{*}{ A Noite } & 4 dezembro & 1914 \\
\hline & $12,14,16,25,27,28$ junho & 1915 \\
\hline & 21 dezembro & 1916 \\
\hline \multirow[t]{2}{*}{ A Notícia } & 12 - 13 dezembro & 1914 \\
\hline & $17-18 ; 20 ; 27-28$ junho & 1915 \\
\hline \multirow[t]{2}{*}{ A Rua } & 5,6 e 8 dezembro & 1914 \\
\hline & $\begin{array}{l}12,15,16,18,19,22,23,25,26 \\
\text { e } 28 \text { de junho }\end{array}$ & 1915 \\
\hline A União & $\begin{array}{l}29 \text { junho; } 4 \text { de julho e } \\
\text { 31dezembro; }\end{array}$ & 1915 \\
\hline Correio da Manhã & $\begin{array}{l}9 \text { abril; } 12,16 \text { e } 27 \text { junho; } 6 \\
\text { julho }\end{array}$ & 1915 \\
\hline Correio da Noite & 16 e 19 junho & 1915 \\
\hline \multirow[t]{2}{*}{ Gazeta de Notícias } & 27 maio; 12 e 16 junho & 1915 \\
\hline & 4 abril e 22 dezembro & 1916 \\
\hline A Època & 12 e 13 junho; 4 e 9 julho & 1915 \\
\hline \multirow[t]{3}{*}{ O Imparcial } & 2 dezembro & 1914 \\
\hline & $\begin{array}{l}5 \text { e } 20 \text { abril; } 16 \text {, e } 19 \text { maio; } 12, \\
13,15,16,19,27 \text { junho }\end{array}$ & 1915 \\
\hline & 18 maio & 1916 \\
\hline \multirow[t]{2}{*}{ O Século } & 28 fevereiro & 1914 \\
\hline & $\begin{array}{l}\text { 14,17, 18, 19, 21, 23, 26, 28,29 } \\
\text { junho; 11 dezembro; }\end{array}$ & 1915 \\
\hline
\end{tabular}




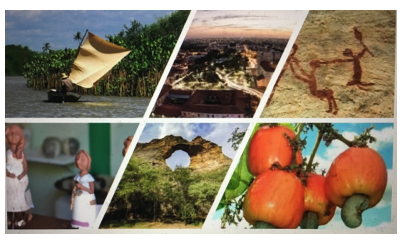

\begin{tabular}{|l|c|c|}
\hline & 12 janeiro; 28 fevereiro; 13 & 1916 \\
\hline O Paiz & 16 dezembro & 1914 \\
\hline & $14,15,16,17$ e 29 junho; & 1915 \\
\hline
\end{tabular}
quadro.

.Elaborado pelo autor a partir dos jornais fonte/objeto da investigação citados no

Fonte: BN, Hemeroteca.

Como se observa no quadro acima, embora muitos jornais da cidade do Rio de Janeiro tivessem noticiado o "caso Hans Heilborn”, destacam-se os jornais $O$ Século, $O$ Imparcial e $A$ Rua, com quase diários comentários. Estes jornais transformavam ações banais e corriqueiras de um administrador do educandário formador de professores em grandes manchetes, que buscavam leitores ávidos de sensacionalismo. Essa propaganda era veiculada principalmente pelos jornais de oposição ao Governo Federal, comandado por Wenceslau Brás, ou de oposição ao prefeito, Rivadávia Corrêa. E desse modo foi difundido o rumor sobre Hans Heilborn, iniciado no $O$ Século, de propriedade de Brício Filho, também um professor da Escola Normal e partícipe da Congregação de professores do educandário.

E que rumor era esse? Ora, se dialogo com Pêcheux (1990) considero, também, que a materialidade ideológica só pode ser apreendida a partir da materialidade linguística do dizer concreto de cada indivíduo. Desse modo, o rumor está, por vezes, nas entrelinhas que antevê e precede o fato em si. O rumor contra Hans Heilborn, que Brício Filho lança na escritura impressa de seu jornal diário, aos poucos impregna o ar, amoldase confortável entre as matérias veiculadas pelos outros noticiosos escritos sobre a guerra contra a Alemanha, recentemente iniciada, e instala-se refastelado no átrio da Escola Normal. E por que assim penso?

Antes da chegada de Hans Heilborn à Escola, em 15 de outubro de 1914, à p. 2, o O Século, anuncia que deverá ser nomeado como Diretor da Escola Normal o Professor José Veríssimo. Em 17 de outubro, à página 2, o mesmo jornal, sob o título de Escola Normal e os leads "Justa Reclamação" e "A última Reforma”, denuncia que a reforma de 


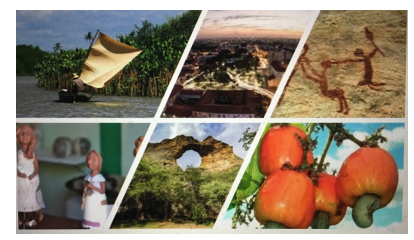

1911, a ser aplicada na Escola Normal, no ano de 1915, prevê um número menor de aulas de Francês, Física e Química, até então estudadas em anos diferentes, que passarão a ser estudadas em um só ano. Reclama ainda o periódico, sem explicar o porquê, que em todos os lugares onde se implantou a reforma educacional, foram preservados os "direitos adquiridos". Sobre o que sussurrava a notícia? Havia direito adquirido que não fora assegurado pela reforma de 1911 ?

Que pretendiam tais notícias? Por que Brício Filho, professor e dono do jornal que publicava matérias desabonadoras sobre a Escola Normal, divulgava os defeitos de seu próprio local de trabalho? Havia uma intenção, uma finalidade na divulgação pela imprensa de fatos corriqueiros de uma escola pública formadora de professores primários? Quem eram os leitores de "O Século" a quem Brício Filho, assim como o restante da imprensa carioca, dirigiam-se?

\section{Cidade e os leitores}

$\mathrm{Na}$ primeira década do século XX o Brasil tinha cerca de 24 milhões (MORTARA, 1941, p.41) de brasileiros em seu vasto território. Na cidade do Rio de Janeiro éramos, de acordo com o censo populacional de 1908 a 1912, o último a ser feito antes da Grande Guerra, cerca de 970 mil habitantes ${ }^{52}$. Desses, até 1912, somente 93.134 frequentavam escolas (elementares, primária, secundária e cursos superiores, públicas e particulares), dos quais, entretanto, só 5.204 alunos concluíam estes cursos, no mesmo período (ibidem p.970). No que tange à imprensa, no Distrito Federal havia, desde 1825, 122 periódicos, mas o número de leitores era pouquíssimo (ibidem). Eram 3.939 professores no Distrito Federal com docência nos cursos elementar, primário, secundário e superiores, em instituições públicas e particulares (ibidem, p.880), quando a imprensa abrigava a vida intelectual da cidade do Rio de Janeiro.

Será que eram assim tão poucos aqueles não letrados? A própria historiografia apresenta caminhos que cruzei buscando marcas e indícios para essa afirmação

\footnotetext{
52975.818 habitantes de acordo com o IBGE, Anuário Estatísticas do Século XX, p. 255.
} 


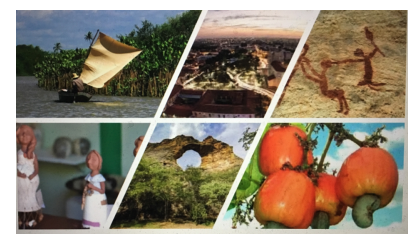

cristalizada. Refiz rotas para mapear os jornais de subúrbio ${ }^{53}$ e os jornais proletários, anarquistas e comunistas, pouco pesquisados pela historiografia, mas escritos e lidos por letrados. Segundo a historiografia que pesquisa este objeto, os jornais alternativos, fora da chamada "grande imprensa", existiram, mapeados, 93 títulos de impressos de memória operária entre 1858 e $1930^{54}$; e 185 títulos, entre 1847 e $1930^{55}$ de jornais a que chamaríamos de "operários", no entanto, a pesquisa ainda peca, reconheço, em termos de quantitativo nessa temporalidade, pela multiplicidade de acervos em mãos de sindicatos, associações e agremiações não acessíveis ainda, ou listados, por detratores diferenciados (proletariado, operariado, etc.).

Os jornais e revistas eram o lugar do escritor ganhar dinheiro, de ter visibilidade para incrementar a venda dos livros que se produzia, de legitimar-se perante o público leitor, como os livros legitimaram-nos frente a seus pares. Dizem os historiadores que não havia muita gente letrada na cidade capital, sede do poder político do Estado brasileiro. Como essa "pequena população" foi capaz de posicionar-se e deflagrar uma rede germanofóbica que atingiu duramente homens e instituições, através da imprensa, que a incentivava divulgando fatos, criando outros e permeando de vocábulos pejorativos aos alemães o texto dos jornais?

Para poder ter uma ideia da importância da imprensa, em termos numéricos, no país e na cidade do Rio de Janeiro (então Distrito Federal), verifiquei um quadro manuscrito, delicadamente desenhado e colorido, sem número mas situado entre as páginas 466 e 467 da publicação do Instituto Brasileiro de Geografia e Estatística (IBGE), o Anuário Estatístico do Brasil. O documento revela que, no ano de 1912, havia, no Brasil, 1.377 periódicos: 1.307 escritos em português, 25 em alemão, 20 em italiano, 6 em polaco, 6 em árabe, 4 em espanhol, 3 em francês, 1 em inglês e 5 em mais de um idioma. Segundo esta fonte, a periodicidade destes impressos é: 149 jornais diários, 677 semanais, 124 quinzenais, 191 mensais e 196 de periodicidade irregular. Destes, 122 periódicos

\footnotetext{
${ }^{53}$ Ver MENDONÇA, 2011.

${ }^{54}$ Ver: KOCHER, 1988.

${ }^{55}$ Ver FERREIRA, 1988.
}

Revista Caminhos da Educação: diálogos, culturas e diversidades. CAEDU/UFPI 102 Teresina, Brasil, v. 1, n. 1, p. 80- 112, janeiro/abril de 2019

DOI: 


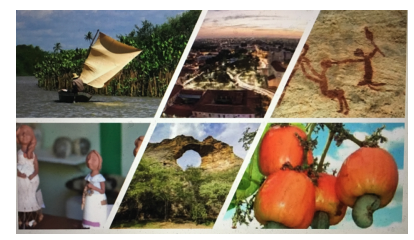

tinham sede na cidade do Rio de Janeiro, tendo a seguinte circulação: 23 diários, 25 semanais, 10 quinzenais, 36 mensais, 11 anuais e 17 com periodicidade irregular. Desses jornais/revistas na cidade do Rio de Janeiro, 113 deles eram escritos em português, 2 em francês, 2 em italiano e 2 em árabe, 1 em inglês e 2 em mais de um idioma. Esse quadro estatístico persiste, em linhas gerais nos primeiros anos da Grande Guerra e foram os periódicos da cidade do Rio de Janeiro aqueles que tomaram partido no conflito, ao lado dos aliados, em sua maioria, especialmente aqueles escritos em português. Os leitores de "O Século", suponho, faziam parte dos letrados em sua maioria. E nesse número de letrados incluo os demais redatores e repórteres dos outros jornais de posição ao governo que reverberavam as notícias que eram publicizadas por Brício Filho.

\section{Conclusão}

A reação germanofóbica dos jornais do Rio de Janeiro, no período 1914-1918, traz â cidade o debate e as tensões entre aliadófilos e germanófilos, frente à Grande Guerra na Europa. Esse debate coloca em lados opostos Hans Heilborn, o diretor de nacionalidade alemã, e professores e alunos francófilos e gera tensões que, ampliadas e difundidas, eram publicizadas pelos jornais diários da cidade do Rio de Janeiro.

Hans Heilborn, por minha análise, nunca foi elemento perigoso à soberania nacional, pelo contrário. Atuara em comissões no estrangeiro para vender o café brasileiro, item mais importante das exportações nacionais naquele momento da primeira década do século XX. O educador, por sua biografia, não militava na política. Era um médico que se dedicou ao magistério seja criando escolas, seja como docente no Ginásio de Petrópolis e no Ginásio Nacional, mas era alemão de nascimento e naquele momento isso era o bastante. Contra Hans Heilborn, além da ideologia francófila que o mantinha como "inimigo", havia a oposição política à Rivadávia Corrêa, que o nomeara. A Rivadávia, ex-ministro da Justiça do governo Hermes da Fonseca, se acumulam na imprensa oposicionista denúncias, que trazia, ainda, do cargo de Ministro que ocupara no 


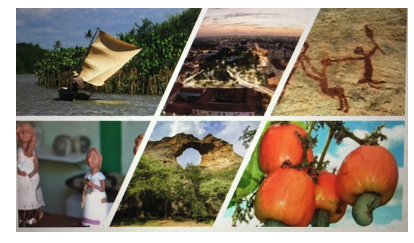

governo Hermes da Fonseca. Por outro lado, politicamente, Hans Heilborn, enquanto alvo dos oposicionistas, era perfeito para o presidente Wenceslau Brás, naquele momento em que os Estados Unidos entravam no conflito europeu e britânicos e franceses perdiam em batalhas. A superioridade alemã definia a guerra tornando a posição econômica do Brasil incerta. Enquanto a imprensa colocava em destaque apenas Hans Heilborn e Rivadávia Corrêa, Wenceslau ignorava-os, deixando o tempo passar. Preocupava o governo Wenceslau a estagnação das importações, que afetariam o equilíbrio fiscal do governo (porque as tarifas de importação eram um extraordinário meio das receitas governamentais).

A imprensa, através das charges, levava o discurso germanofóbico a todos os habitantes da cidade-capital (os que liam e os que não liam). Esse discurso ideológico interessava ao prefeito, que deixava de protagonizar sozinho as manchetes dos jornais de oposição, e ao presidente da república, que continuava a comerciar com os germânicos apesar da Guerra, em momento de poucos compradores das exportações agrícolas brasileiras. Por estas razões as inúmeras solicitações de Hans Heilborn para sua exoneração do cargo de diretor da Escola Normal não foram atendidas pelo Diretor de Instrução, Azevedo Sodré e pelo prefeito, Rivadávia Corrêa. Mas a enorme repercussão dos fatos ocorridos na Escola Normal impedia àquelas autoridades a manutenção de Hans Heilborn no cargo!

Hans Heilborn agiu na Escola Normal como qualquer diretor de educandário procurando manter a ordem e a disciplina. No entanto, suas ações como administrador foram redimensionadas e dessa forma reinterpretadas no tempo atípico e belicoso, em uma cidade francófila. Seus atos foram impregnados pela germanofobia dos professores que incitavam as alunas, que também eram influenciadas pela imprensa de uma cidade francófila e ignoradas por um presidente da república, residente na mesma cidade, muito preocupado com o comércio internacional e com o que o país podia perder economicamente. 


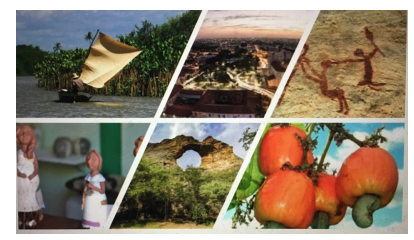

Hans Heilborn morreu cerca de um ano após seu pedido de exoneração do cargo de diretor da Escola Normal. Não foi enterrado, como os demais diretores até então, no Cemitério São João Baptista, mas em Petrópolis. Morrei provavelmente desgostoso. Como homenagem póstuma a Escola Normal não funcionou no dia de seu enterro. Não conta que nenhum representante do educandário tenha comparecido ao féretro.

\section{Referências}

ALVES, Francisco das Neves. Imprensa Caricata Rio-grandense e Crítica Política ao Final do Império. Biblos - Revista do Instituto de Ciências Humanas e da Informação da Universidade Federal do Rio Grande, vol.8. p. 139-146. RS, Rio Grande: Universidade Federal do Rio Grande, 1996.

BENCHIMOL, Jaime L. O Brasil e o mundo germânico na medicina e saúde pública (1850-1918): uma história a voo de pássaro. História. v.32, n.2, São Paulo: jul./dez. 2013. p. 105-138

BORGES, Maria Eliza Linhares. Representações do Brasil Moderno para ler, ver e ouvir no circuito dos Museus Commerciais europeus, 1906 a 1908. História, Franca, v. 26, n. 2, , 2007, p. 92-117.

BOSI, Alfredo. O Ser e o Tempo na Poesia. São Paulo: Companhia das Letras, 1977.

BRANDÃO, Raul e LEITÃO, Hilário (dir.). Almanaque do Correio da Manhã, 1944. Rio de Janeiro: Estabelecimento de Artes Gráficas C. Mendes Júnior. nº 1,1944). p.. 2 20 


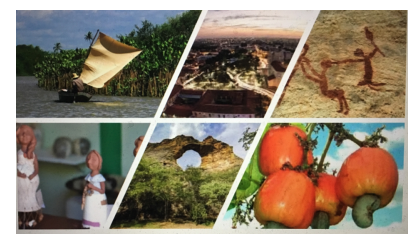

BULHÕES, Marcelo. João do Rio e os gêneros jornalísticos no início do século XX. Revista FAMECOS. Pontifícia Universidade Católica (PUC) - RS. Porto Alegre. $\mathrm{n}^{\mathrm{o}}$ 32, abril de 2007 p. $78-84$

CASAZZA, Ingrid Fonseca. O Jardim Botânico do Rio de Janeiro: um lugar de ciência (1915-1931). Dissertação (Mestrado em História das Ciências e da Saúde). Fundação Oswaldo Cruz. Rio de Janeiro, RJ: Fundação Oswaldo Cruz. Casa de Oswaldo Cruz. Programa de Pós-Graduação em História das Ciências e da Saúde, 2011.

CHARTIER, Roger. Introdução. Por uma sociologia histórica das práticas culturais. In: . A História Cultural entre práticas e representações. Col. Memória e sociedade. Trad. Maria Manuela Galhardo. Rio de Janeiro: Bertrand Brasil, 1990, p. 1328.

O mundo como representação. In: A beira da falésia: a história

entre incertezas e inquietude. Trad. Patrícia Chittoni Ramos. Porto Alegre: Ed. Universidade/UFRGS, 2002a, p. 61-80.

Do palco à página: publicar teatro e ler romances na época moderna (séculos XVI-XVIII). Trad. Bruno Feitler. Rio de Janeiro: Casa da Palavra, 2002b.

CHÉRADAME, André. Le plan pangermaniste démasqué: le redoutable piège berlinois de 'la partie nulle'. França: Hardpress Publishing, 2013.

COSTA, Lailton Alves da Costa. Gêneros Jornalísticos . In: MELO, José Marques e ASSIS, Francisco (Orgs.). Gêneros Jornalísticos no Brasil. São Bernardo do Campo: Universidade Metodista de São Paulo, 2010. p.43-83. 


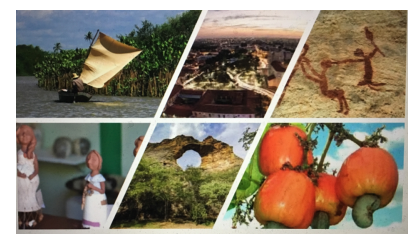

DIDIER, Carlos. Orestes Barbosa: repórter, cronista, poeta. Rio de Janeiro: Ed. Agir, 2005.

EDMUNDO, LUIZ. O Rio de Janeiro do meu Tempo. Brasília: Senado Federal, 2003 Disponível em http://www2.senado.leg.br/bdsf/item/id/1071 Acesso: 21/04/2015

ERTZOGUE, Marina Haizenreder. Territórios da solidão: o homem finissecular na escrita de Alcindo Guanabara. Revista Mosaico, Programa de Pós-Graduação em História da PUC-Goiás, v.3, n.2, jul./dez. 2010. p.191-198

FANAIA, João Edson. Verbete Azeredo, Antônio. In: ABREU, Alzira Alves de e BELOCH, Israel (Coords.) Dicionário histórico-biográfico da Primeira República (1889-1930). Rio de Janeiro: Editora FGV, 2015 Disponível em http://cpdoc.fgv.br/sites/default/files/verbetes/primeirarepublica/AZEREDO,\%20Ant\%C3\%B4nio.pdf Acesso: 4/8/2017

FERREIRA, Maria Nazareth. Imprensa operária no Brasil. São Paulo: Editora Ática, 1988.

GERTZ, René Ernaini. O Perigo Alemão. $2^{\mathrm{a}}$ ed. RS, Porto Alegre: Editora da UFRGS, 1998.

. Os "súditos alemães” no Brasil e a "pátria-mãe” Alemanha. Espaço Plural - Ano IX $\bullet \mathrm{n}^{\mathrm{o}} 19 \cdot 2^{\circ}$ Semestre 2008.p. 67-73

A Construção de uma Nova Cidadania. In: Os Alemães no Sul do Brasil: Cultura, Etnicidade e História. Canoas: Ed. da ULBRA, 1994. 


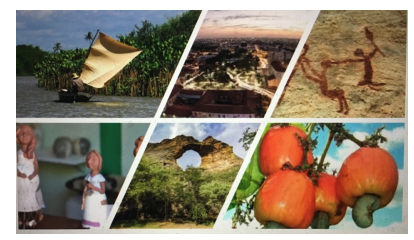

GUIMARÃES, Lúcia Maria Paschoal. Circulação de saberes, sociabilidades e linhagens historiográficas: dois congressos de História Nacional (1914 e 1949). In: GUIMARÃES, Manoel Luiz Salgado. Estudos sobre a escrita da história. Rio de Janeiro: 7Letras, 2006, p. 162-181.

HOBSHAWM, Eric. Era dos Extremos : o breve século XX : 1914-1991. Trad.: Marcos Santarrita. São Paulo: Companhia das Letras, 1995.

IBGE. Anuário Estatístico do Brasil. Disponível em https://biblioteca.ibge.gov.br/visualizacao/periodicos/20/aeb_2016.pdf Acesso $8 / 8 / 2018$ . Estatísticas do Século XX. Disponível em https://biblioteca.ibge.gov.br/visualizacao/livros/liv37312.pdf Acesso 8/8/2018

KOCHER, Bernardo; LOBO, Eulalia Maria Lahmeyer; MARTINS, Ismênia de Lima. Guia dos jornais operários do Rio de Janeiro. Rio de Janeiro: Universidade Federal Fluminense, 1988.

LACAN, Jacques. O estádio do espelho como formador da função do eu. In: LACAN, Jacques. Escritos. (Trad Vera Ribeiro). Rio de Janeiro: Zahar, 1998, p.98- 103

LACOMBE, Américo Jacobina. Afonso Pena e sua época. Rio de Janeiro: J. Olympio Editora, 1986.

LEAL, Carlos Eduardo. Verbete $O$ Paiz. In: ABREU, Alzira Alves de e BELOCH, Israel (Coords.) Dicionário histórico-biográfico da Primeira República (1889-1930). Rio de Janeiro: Editora FGV, 2015 Disponível em 


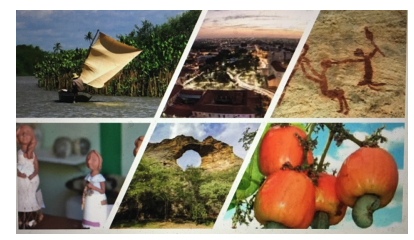

http://cpdoc.fgv.br/sites/default/files/verbetes/primeirarepublica/AZEREDO, $\% 20 \mathrm{Ant} \% \mathrm{C3} \% \mathrm{~B} 4$ nio.pdf Acesso: 4/8/2017

MENDES, Laine Soares. A vida elegante: a invenção das damas na sociedade da belle époque carioca (rio de janeiro -1903 a 1904). Anais. Encontro Internacional e XVIII Encontro de História da Anpuh-Rio. Niterói, RJ: ANPUH/Universidade Federal Fluminense (UFF), 2018.

MENDONÇA, Leandro Climaco. Nas margens: experiências de suburbanos com periodismo (1880-1920). Dissertação (Mestrado em História Social). Instituto de Ciências Humanas e Filosofia. Departamento de História. Universidade Federal Fluminense. Niterói: UFF, 2011

MORTARA, Giorgio. Estudos sobre a utilização do censo demográfico para a reconstituição

das estatísticas do movimento da população do Brasil. Revista Brasileira de Estatística. ano II, no. 5, vol. III. Rio de Janeiro: IBGE, jan./mar. 1941, p. 41-43.

MORASCO, Cibele Cristina. Fora do Palco dentro da Vida: O Contista Arthur Azevedo e o Rio de Janeiro de sua época. Dissertação (Mestrado em Estudos Literários). Faculdade de Ciências e Letras. Universidade Estadual Paulista "Júlio de Mesquita Filho". SP, Araraquara, 2008.

NORA, Pierre. Entre memória e história: a problemática dos lugares. Projeto História, São Paulo, n.10, dez. 1993, p.7-28.

. O retorno do fato. In: LE GOFF, Jacques; NORA, Pierre (orgs.). História: novos problemas. Rio de Janeiro: Francisco Alves, 1979. p. 179-193. 


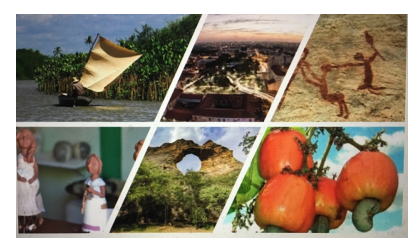

NUNEZ, Ronal Leon. Guerra do Paraguai: revolução e genocídio. Trad.: Paula Maffei.São Paulo: Ed. Sunderman, 2011

PÊCHEUX, Michel. Delimitações, Inversões, Deslocamentos. Cadernos de Estudos Linguísticos, n.19. Campinas: Unicamp. 1990, p. 7-24

PIRES, Livia Claro. A Liga Brasileira pelos Aliados e o Brasil na Primeira Guerra Mundial. Anais... XXVI Simpósio Nacional de História São Paulo: ANPUH, julho 2011 pp. $1-15$

RIBEIRO, Pedro Krause. O“povo" na retórica da charge: Zé Povinho e Zé Povo na imprensa luso-brasileira (1875-1907). Anais... II Encontro Nacional de Estudos da Imagem. Centro de Letras e Ciências Humanas da Universidade Estadual de Londrina. Paraná, Londrina: Universidade Estadual de Londrina/, 2009.

RICOEUR, Paul. La mémoire, l'histoire, l'oubli. Paris: Éditions du Seuil, 2000.

AUTOR. Escola Normal do Distrito Federal: por trás da modernidade civilizatória da cidade do Rio de Janeiro (1911 - 1920) Revista Contemporânea de Educação, vol. 8, n. 15, UFRJ, janeiro/julho de 2013, pp.133-153.

Marcas da memória silenciada da escola normal do Distrito Federal nas cartas de leitores do jornal A Época. In: MIGNOT, Ana Chrystina Venancio (Org.). $A$ ilusão do leitor: cartas, imprensa e educação. Curitiba, Paraná: Editora CRV, 2018, , p. $37-58$ 


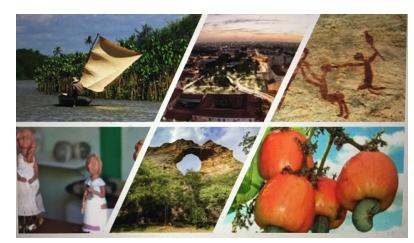

. Por trás das janelas na Praça da Aclamação: a Escola Normal republicana. In: VI Seminário internacional as redes educativas e as tecnologias. "Teorias sociais na contemporaneidade". Rio de Janeiro: Universidade do Estado do Rio de Janeiro (UERJ), 2011.

. "O caso da Escola Normal": no rastro das charges da revista O Malho (1914-1915). Revista Dia-logos, Programa de Pós-Graduação em História Política da UERJ; v. 11, n. 01, Rio de Janeiro: UERJ, jan.-jun 2017, p. 82-99

Rua São Cristóvão, 18: Escola Normal do Distrito Federal (1911-1920)

Disponível em https://pt.scribd.com/presentation/166706296/RUA-SAO-CRISTOVAO$\underline{18}$ Acesso 13/04/2011

SEYFERTH, Giralda. A dimensão cultural da imigração. Revista Brasileira de Ciências Sociais - vol. 26 n $^{\circ} 77.2011$, p. 47-62

SILVEIRA, Alfredo Balthazar da. História do Instituto de Educação. Distrito Federal: Oficinas Gráficas da Secretaria Geral de Educação e Cultura, 1954.

SONDHAUS, Lawrence. A Primeira Guerra Mundial. Trad, Roberto Cataldo. São Paulo: Contexto, 2013.

SORIANO NETO, Manoel. As contribuições da primeira guerra mundial para a arte da guerra. Revista Aeronáutica ( do Clube de Aeronáutica) nº 288, Rio de Janeiro, 2014 


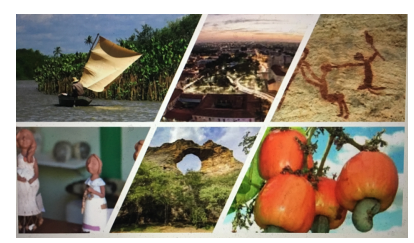

TURRIL, H. B. John Christopher Willis In: ROYAL SOCIET PUBLISHING, Biograph Memoirs, 1958, p. 352-359 Disponível em https://royalsocietypublishing.org/ Acesso em 21/03/2019

VERRUMO, Marcel Antonio. Repórter-cronista da Belle Èpoque carioca: o jornalismo vertiginoso de João do Rio. Dissertação (Mestrado em Comunicação Social). Programa de Pós-Graduação em Comunicação Social. Universidade do Estado de São Paulo (UNESP). São Paulo, Bauru: Universidade do Estado de São Paulo (UNESP), 2014. 